\title{
Homotrinuclear Complexes of [30]Trithiadodecaazahexaphyrine with Transition Metals: Ni(II), Cu(II) and Mn(II)
}

\author{
Evgeny N. Ivanov, ${ }^{a}$ Olga N. Trukhina, ${ }^{\mathrm{b}}$ Oskar I. Koifman, ${ }^{a}$ Mikhail K. Islyaikin® ${ }^{\mathrm{a}}$ \\ Dedicated to Professor Tomas Torres Cebada on the occasion of his 65th birthday
}

anternational Research Laboratory on Nanomaterials, Research Institute of Macroheterocycles, Ivanovo State University of Chemistry and Technology, 153000 Ivanovo, Russian Federation

bDepart. de Química Orgánica (C-I), Universidad Autónoma de Madrid, Cantoblanco, 28049 Madrid, Spain

${ }^{\circledR}$ Corresponding authorE-mail: islyaikin@isuct.ru

\begin{abstract}
Homotrinuclear complexes were synthesized by reaction of [30] trithiadodecaazahexaphyrine (hemihexaphyrazine) with nickel(II), copper(II) or manganese(II) acetates in phenol. The compounds were characterized by UV-Vis, IR spectroscopy, mass-spectrometry and elemental analysis. Study of thermal behavior of manganese complex has shown high thermal stability. The structure of a cationic copper complex observed in mass-spectrum was elucidated by quantum chemistry calculations at the DFT level.
\end{abstract}

Keywords: Homotrinuclear complexes, expanded porphyrinoids, [30]trithiadodecaazahexaphyrine, hemihexaphyrazine.

\section{Гомотринуклеарные комплексы [30]тритиадодекаазагексафирина с переходными металлами: $\mathrm{Ni}(\mathrm{II}), \mathrm{Cu}(\mathrm{II})$ и $\mathrm{Mn}(\mathrm{II})$}

\author{
Е. Н. Иванов, ${ }^{\text {a }}$ О. Н. Трухина, ${ }^{\text {b O. И. Койфмман, }}{ }^{a}$ М. К. Исляйкин ${ }^{\text {@ }}$ \\ Посвящается профессору Томасу Торресу Себада по случаю 65-летнего юбилея
}

\footnotetext{
а Международная научно-исследовательская лаборатория наноматериалов, НИИ химии макрогетероциклов, Ивановский государственный химико-технологический университет, 153000 Иваново, Россия

'Департамент органической химии, Мадридский автономный университет, Кантобланко, 28049 Мадрид, Испания

${ }^{\circledR}$ E-mail: islyaikin@isuct.ru
}

\begin{abstract}
Взаимодействием [30]тритиадодекаазагексафирина с ацетатами никеля(II), меди(II) и марганияа(II) в феноле синтезированы гомотринуклеарные комплексы. Соединения охарактеризованы данными УФ-, ИК-спектроскопии, масс-спектрометрии и элементного анализа. Изучение термогравиметрическим методом показало, что марганцевый комплекс обладает высокой термической стабильностью. Структура катионного комплекса с медью, зафиксированного в масс-спектре, была подтверждена квантово-химическими расчетами по методу DFT.
\end{abstract}

Ключевые слова: Гомотринуклеарные комплексы, порфириноиды с расширенной координационной полостью, [30]тритиадодекаазагексафирин, гемигексафиразин. 


\section{Introduction}

Since the beginning of this millennium considerable efforts have been devoted to the synthesis, structure elucidation and study of the properties of new macroheterocyclic compounds (Mc's) with enlarged coordination cavities. ${ }^{[1-6]}$ A principal aspect derived from structures of these compounds is aromaticity of central core and applicability of Hückel's rule to describe its electronic structure. ${ }^{[7-9]}$ Among expanded compounds, Mc's of ABABAB-type (hemihexaphyrazine, $\mathbf{H}_{3} \mathbf{H h p}$ ) containing six consecutively interlinked 1,3,4-thiadiazole (A) and isoindole (B) subunits bridged by nitrogen atoms ${ }^{[10,11]}$ induce a particular interest. Indeed, various substituted macroheterocyclic compounds of this type were synthesized to date ${ }^{[12-18]}$ and their structures were confirmed by gas electron diffraction (GED) ${ }^{[19,20]}$ and single crystal X-ray diffraction ${ }^{[21]}$ methods. It was established that compounds of this type have a nonaromatic macrocyclic backbone containing 30 carbon and nitrogen atoms which form an expanded coordination cavity compared to that of porphyrins and phthalocyanines.

This extended macrocyclic system is able to bind up to three transition metal atoms. ${ }^{[10,11,22]}$ Since nonsubstituted $\mathbf{H}_{3} \mathbf{H h p}$ is only slightly soluble in organic solvents, ${ }^{[23]}$ information on the metal complexes of these compounds was limited by synthesis of metal complexes of substituted hemihexaphyrazines. Therefore, the aim of this work is the synthesis of transition metal complexes based on the unsubstituted $\mathbf{H}_{\mathbf{3}} \mathbf{H h p}$.

\section{Experimental}

MALDI-TOF spectra of metal complexes were performed on a Bruker Reflex III instrument in Universidad Autónoma de Madrid, Spain and MALDI-TOF spectra of metal free $\mathbf{H}_{3} \mathbf{H h p}$ on Axima Confidence, Shimadzu (Ivanovo State University of Chemistry and Technology). UV-vis spectra were recorded by a HELIOS ZETA spectrophotometer using mixture of phenol and methanol $(1: 1 \mathrm{v} / \mathrm{v})$ as the solvent ( $1 \mathrm{~cm}$ path length quartz cell). Elemental analysis was performed on Flach EA 1112 instrument. IR spectra were recorded on Avatar 360 FT-IR ESP spectrophotometer (ISUCT).

Thermogravimetric analysis (TGA) and differential scanning calorimetry (DSC) were carried out on STA 449 F1 "Jupiter"(Netzsch, Germany) unit at a heating rate of $5{ }^{\circ} \mathrm{C} \cdot \mathrm{min}^{-1}$ under atmosphere of argon-oxygen.

\section{Quantum Chemistry Details}

Quantum chemistry calculations have been carried out by the density functional theory method (DFT, B3LYP functional) with the use of 6-31G(d,p) basis set for describing the electron shells of C, N, $\mathrm{O}, \mathrm{S}$, and $\mathrm{H}$ atoms and an effective core pseudopotential LANL2DZ ${ }^{[24]}$ for $\mathrm{Cu}$ atoms. Since this cationic complex is an open shell system, a formalism of UHF has been applied. The results of second derivatives calculations showed no imaginary frequencies. All calculations were carried out using the Firefly QC package, ${ }^{[25]}$ which is partially based on the GAMESS (US) ${ }^{[26]}$ source code. ChemCraft software ${ }^{[27]}$ was applied for preparation of input data file, as well as for processing and visualization of the computed results.

\section{Synthesis of $\boldsymbol{H}_{3} \boldsymbol{H h p}(\mathbf{1})$}

A solution of phthalonitrile $(0.64 \mathrm{~g}, 5.0 \mathrm{mmol})$ and 2,5-diamino-1,3,4-thiadiazole ( $0.58 \mathrm{~g}, 5.0 \mathrm{mmol})$ in ethylene glycol $(150 \mathrm{ml})$ was stirred at reflux for $24 \mathrm{~h}$. After cooling to room temperature, the reaction mixture was poured into water $(100 \mathrm{ml})$. The precipitate was filtered, triturated repeatedly with hot solvents: DMF, water, methanol, acetone and hexane. Yield $23 \%$. IR $(\mathrm{KBr})$ $v \mathrm{~cm}^{-1}: 3420,2969,2926,2843,2228,1624,1467,1404,1307$ 1217, 1092, 1041, 852, 804, 701. UV-Vis $\left(\mathrm{C}_{2} \mathrm{H}_{2} \mathrm{Cl}_{4}, c=0.369 \cdot 10^{-4}\right.$ mol/1) $\lambda_{\text {max }}$ nm (A, u.abs.): 391 (0.35), 411 (0.32), 464 (0.086), 501 (0.06). MS (MALDI-TOF, $\alpha$-cyano-4-hydroxycinnamic acid) $\mathrm{m} / \mathrm{z}$ : $681.8[\mathrm{M}+\mathrm{H}]^{+}$. Calcd for $\left[\mathrm{C}_{30} \mathrm{H}_{15} \mathrm{~N}_{15} \mathrm{~S}_{3} \mathrm{H}^{+}\right]$: $\mathrm{EM}=681.7$. Found, \%: C, 52.85; H, 2.22; N, 30.82; S, 14.11. Calcd. for $\mathrm{C}_{30} \mathrm{H}_{15} \mathrm{~N}_{15} \mathrm{~S}, \%$ : C, 52.13; H, 2.29; N, 31.17; S, 13.92 .

\section{Synthesis of [30]Trithiadodecaazahexaphyrine Complexes (2-4)}

General procedure: The corresponding metal acetate $(0.6 \mathrm{mmol})$ was added to a solution of $\mathbf{H}_{3} \mathbf{H h p}(0.14 \mathrm{mmol})$ in phenol $(5 \mathrm{~g})$ at $45{ }^{\circ} \mathrm{C}$. Then the reaction mixture was stirred for $5 \mathrm{~h}$ at $100{ }^{\circ} \mathrm{C}$ and after that was poured into $150 \mathrm{~mL}$ of hot water. A precipitate was filtered and vigorously washed with hot water, DMF, acetone, hexane and dried under vacuum at $60^{\circ} \mathrm{C}$ for $4 \mathrm{~h} .2-4$ are dark brown powders which are insoluble in common organic solvents, very low soluble in DMF and pyridine, soluble in phenol.

2, Cu-complex, was obtained following the general procedure using $0.139 \mathrm{~g}(0.55 \mathrm{mmol})$ of $\mathrm{Cu}\left(\mathrm{CH}_{3} \mathrm{COO}\right)_{2} \cdot 4 \mathrm{H}_{2} \mathrm{O}$ and $0.1 \mathrm{~g}$ $(0.14 \mathrm{mmol})$ of $\mathbf{H}_{3} \mathbf{H h p}$. Yield $42 \%$. UV-Vis (phenol-methanol 1:1 $\left.\mathrm{v} / \mathrm{v}, c=0.678 \cdot 10^{-4} \mathrm{~mol} / \mathrm{l}\right) \lambda_{\text {max }} \mathrm{nm}$ (A, u.abs.): $386(0.37), 421(0.39)$, 514 (0.07). IR (KBr) $v \mathrm{~cm}^{-1}: 3435,2920,1591,1510.1430,1290$, 1190, 1100, 816, 719, 498. MS (MALDI-TOF, dithranol) $\mathrm{m} / \mathrm{z}: 868.9$, calc. for $\left[\mathrm{C}_{30} \mathrm{H}_{12} \mathrm{Cu}_{3} \mathrm{~N}_{15} \mathrm{~S}_{3}\right]^{+}: \mathrm{EM}=868.8[\mathrm{Hhp}+3 \mathrm{Cu}]^{+} ; 884.9$, calc. for $\left[\mathrm{C}_{30} \mathrm{H}_{12} \mathrm{Cu}_{3} \mathrm{~N}_{15} \mathrm{OS}_{3}\right]^{+}: \mathrm{EM}=884.3[\mathrm{Hhp}+3 \mathrm{Cu}+\mathrm{O}]^{+}$. Found, \%: $\mathrm{C}$, 43.83; H, 1.98; N, 24.27; S, 10.05. Calcd for $\mathrm{C}_{30} \mathrm{H}_{15} \mathrm{Cu}_{3} \mathrm{~N}_{15} \mathrm{~S}, \%$ : C, 41.45; H, 1.39; N, 24.17; S, 11.06 .

3, Ni-complex, was obtained following the general procedure using $0.136 \mathrm{~g}(0.55 \mathrm{mmol})$ of $\mathrm{Ni}\left(\mathrm{CH}_{3} \mathrm{COO}\right) \cdot 4 \mathrm{H}_{2} \mathrm{O}$ and $0.1 \mathrm{~g}$ (0.14 mmol) of $\mathbf{H}_{3} \mathbf{H h p}$. Yield $61 \%$. IR (KBr) $v_{\mathrm{cm}}^{-1}: 3431,2922$, 2853, 1619, 1537, 1430, 1060, 781, 478 UV-Vis (phenol-methanol $\left.1: 1 \mathrm{v} / \mathrm{v}, c=0.690 \cdot 10^{-4} \mathrm{~mol} / \mathrm{l}\right) \lambda_{\max }$ nm (A, u.abs.): 364 (0.58), 450 (0.97), 524 (0.39). MS (MALDI-TOF, dithranol) $\mathrm{m} / \mathrm{z}: 853.9$, calc. for $\left[\mathrm{C}_{30} \mathrm{H}_{12} \mathrm{Ni}_{3} \mathrm{~N}_{15} \mathrm{~S}_{3}\right]^{+}: \mathrm{EM}=853.9[\mathrm{Hhp}+3 \mathrm{Ni}]^{+} ; 869.9$, calc. for $\left[\mathrm{C}_{30} \mathrm{H}_{12} \mathrm{Ni}_{3} \mathrm{~N}_{15} \mathrm{OS}_{3}\right]^{+}: \mathrm{EM}=869.9[\mathrm{Hhp}+3 \mathrm{Ni}+\mathrm{O}]^{+}$. Found, \%: C, 43.83; H, 1.89; N, 24.27; $\mathrm{S}, 11.05$. Calcd for $\mathrm{C}_{30} \mathrm{H}_{15} \mathrm{Cu}_{3} \mathrm{~N}_{15} \mathrm{~S}, \%$ : $\mathrm{C}$, $42.15 ; \mathrm{H}, 1.42 ; \mathrm{N}, 24.58 ; \mathrm{S}, 11.25$.

4, Mn-complex, was obtained following the general procedure using $0.162 \mathrm{~g}(0.7 \mathrm{mmol})$ of $\mathrm{Mn}\left(\mathrm{CH}_{3} \mathrm{COO}\right)_{2} \cdot 4 \mathrm{H}_{2} \mathrm{O}$ and $0.15 \mathrm{~g}$ $(0.22 \mathrm{mmol})$ of $\mathbf{H}_{3} \mathbf{H h p}$. Yield $20 \%$. IR (KBr) $v \mathrm{~cm}^{-1}$ : 3448, 3287, 2914, 1628, 1515, 1500, 1468, 1406, 1319, 1300, 1219, 1041, 852, 780, 732, 703, 636, 486, 437. UV-Vis (phenol-methanol 1:1 $\left.\mathrm{v} / \mathrm{v}, c=0.369 \cdot 10^{-4} \mathrm{~mol} / \mathrm{l}\right) \lambda$ nm (A, u.abs.): $416(0.39), 433(0.38)$, 540 (0.21). MS (MALDI-TOF, dithranol) $\mathrm{m} / \mathrm{z}: 842.0$. Calcd. for $\left[\mathrm{C}_{30} \mathrm{H}_{12} \mathrm{Mn}_{3} \mathrm{~N}_{15} \mathrm{~S}_{3}\right]^{+}: \mathrm{EM}=842.9[\mathbf{H h p}+3 \mathrm{Mn}]^{+}$. Found, \%: C, 43.20; $\mathrm{H}, 1.93 ; \mathrm{N}, 24.82 ; \mathrm{S}, 10.87$. Calcd for $\mathrm{C}_{30} \mathrm{H}_{15} \mathrm{Mn}_{3} \mathrm{~N}_{15} \mathrm{~S}, \%$ : C, 42.72; H, 1.43; N, 24.91; S, 11.40 .

\section{Results and Discussion}

One of the most prevalent synthetic methods to gain access to macroheterocyclic compounds is reaction of substituted and unsubstituted phthalonitriles or their functional derivatives with aromatic diamines in appropriate solvents. As usual, the reaction of 1,3-diamines in the condensation results in four membered macroheterocyclic compounds of ABAB-type formation. ${ }^{[28]}$ However, utilization of 2,5-diamino-1,3,4-thiadiazole as starting material led to a new class of macroheterocyclic compounds of ABABAB type. ${ }^{[10,11]}$ Herein, a nonsubstituted $\mathbf{H}_{3} \mathbf{H h p}$ was obtained by condensation of phthalonitrile and 2,5-diamino-1,3,4-thiadiazole in 
phenol. ${ }^{[23]}$ To avoid the use of this highly toxic solvent, we have established a new synthetic protocol, employing ethylene glycol as a reaction medium (Scheme 1). Thus, we found out that compound $\mathbf{H}_{3} \mathbf{H h p}$ can be obtained in $23 \%$ yield in refluxing ethylene glycol in $26 \mathrm{~h}^{[23]}$ The product obtained was characterized by MALDI TOF, IR, UV-Vis spectroscopy, and elemental analysis, and its spectroscopic parameters agree well with those reported elsewhere. ${ }^{[21,23]}$

However, efficient metallation of $\mathbf{1}$ could be only achieved in phenol as a solvent, employing acetates of copper(II), nickel(II) and manganese(II) in homogenous medium (Scheme 1), where reagents are present in sufficiently high concentrations. Following the same procedure, metal complexes 2-4 were prepared. During synthesis, the characteristic color change of the reaction solution took place, with color turning from orange to brown. It has been found that complexes formation was finished within 4 hours in all cases.

Then hot dark brown mass was poured into water and vigorously washed with hot water to eliminate phenol. After that the precipitates were carefully washed by hot solvents: DMF, acetone, hexane and the precipitates were dried under vacuum. The yields of 2-4 are in range of 20-61\% which may be explained by loss of products during phenol elimination and their different solubility in DMF.

Metallocomplexes 2-4 were characterized by MS (MALDI-TOF), UV-vis, IR data and elemental analysis. Mass spectrum of $\mathrm{Cu}$-complex $\mathbf{2}$ displays a low intensity peak at $868.9 \mathrm{Da}$ which corresponds to $[\mathbf{H h p}+3 \mathrm{Cu}]^{+}$and major peak at $884.9 \mathrm{Da}$ of $[\mathbf{H h p}+3 \mathrm{Cu}+\mathrm{O}]^{+}$(Figure 1). Isotope distributions of the signals are in good agreement with those derived from theoretical calculations. It's worthy to note that

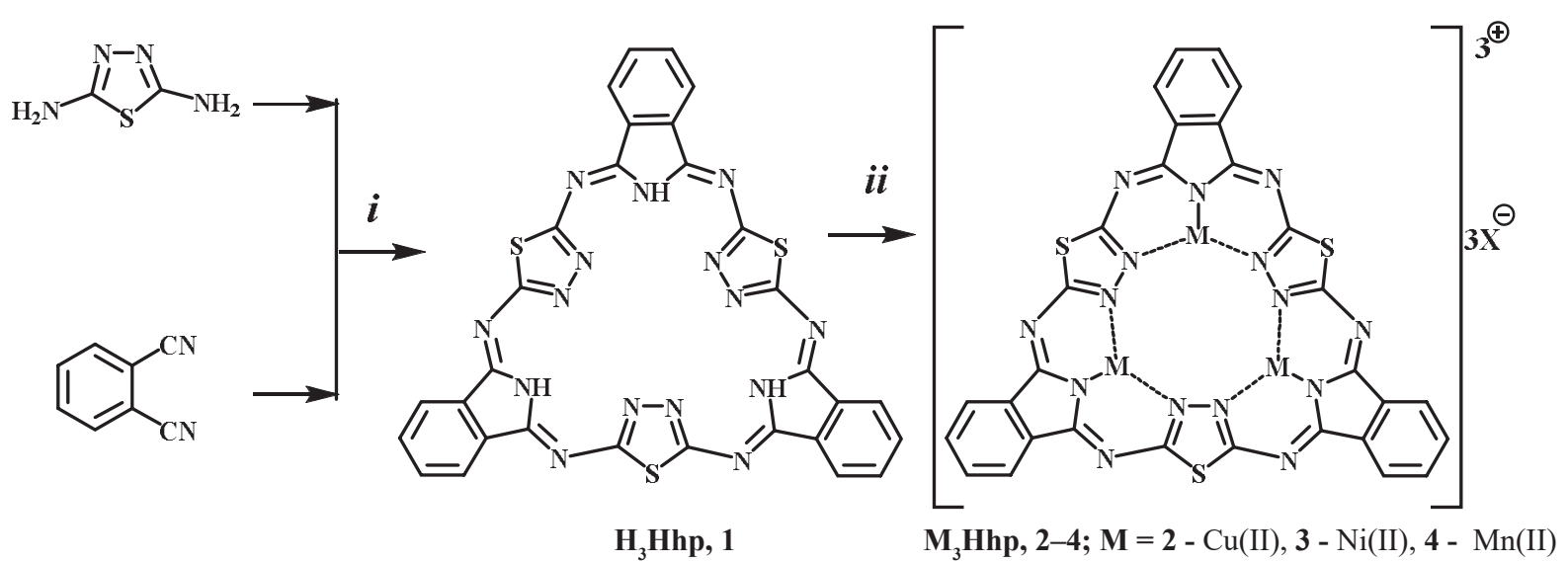

Scheme 1. Synthesis of hemihexaphyrazine 1 and its homotrinuclear complexes with $\mathrm{Cu}(\mathrm{II}) \mathbf{2}, \mathrm{Ni}(\mathrm{II}) \mathbf{3}, \mathrm{Mn}$ (II) 4: $i$ - ethylene glycol, reflux, $26 \mathrm{~h}$; $i i-$ phenol, $5 \mathrm{~h}$ at $100^{\circ} \mathrm{C}$.

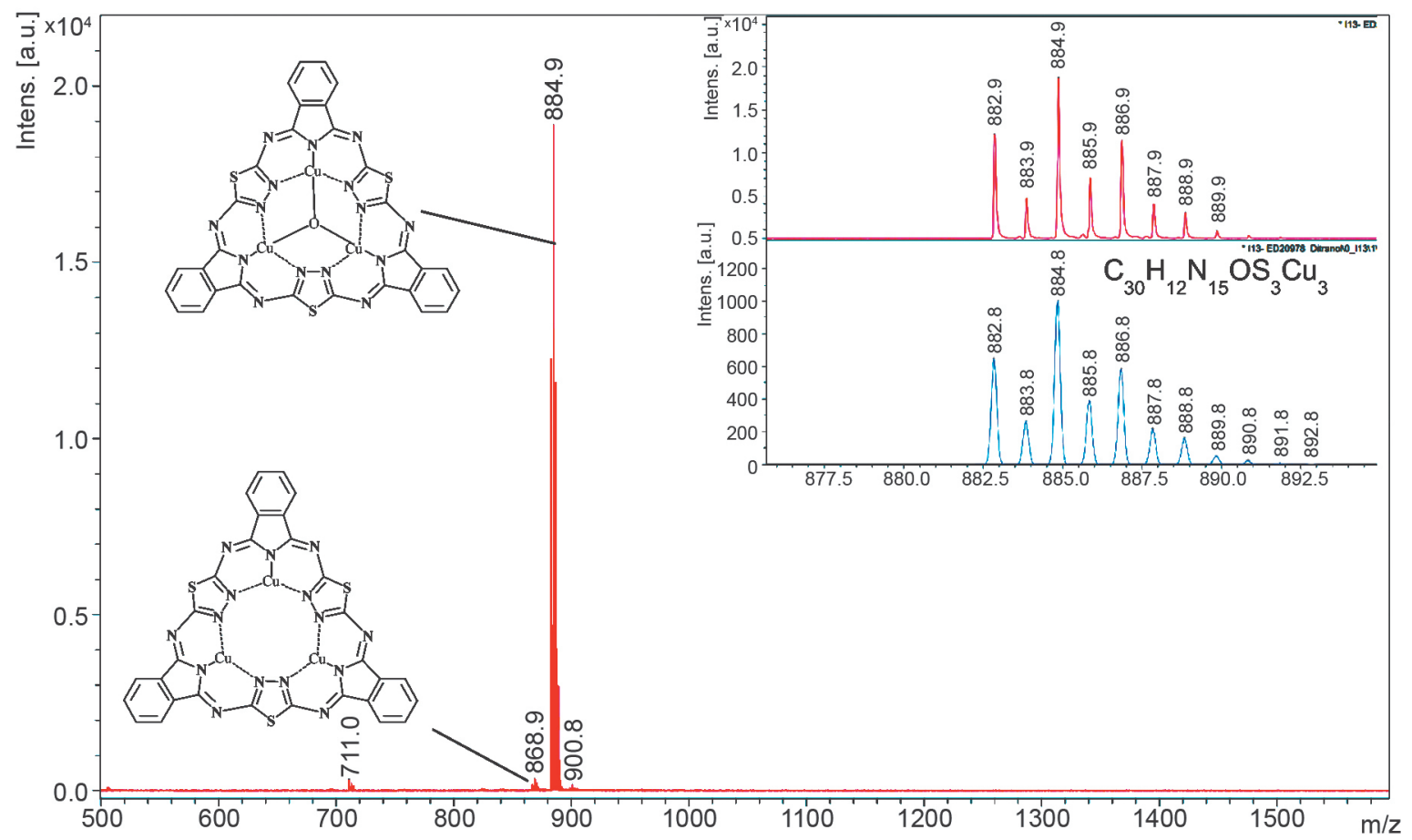

Figure 1. MALDI-TOF spectrum (dithranol) of 2. Insets: isotopic distributions of the main peak at 884.9 Da (above); calculated isotopic pattern for $[\mathrm{Hhp}+3 \mathrm{Cu}+\mathrm{O}]^{+}$(below). 
no signals corresponding to metal free $\mathbf{H}_{3} \mathbf{H h p}$ or complexes of $1: 1$ or $2: 1$ structures were detected in the spectrum.

The formation of the $[\mathrm{Hhp}+3 \mathrm{Cu}+\mathrm{O}]^{+}$detected in the MS may occur during both synthesis and MALDI-TOF experiment. This phenomenon is not clear yet and will be under consideration in the future. Since this cationic complex was found to be stable in gas phase, theoretical method was used to elucidate its structure. It was assumed that oxygen atom can be located in the center of molecule. Full geometry optimization carried out at DFT level led to a plane structure corresponding to the minimum of potential energy surface with symmetry near to $\mathrm{D}_{3 \mathrm{~h}}$ point group (Figure 2).

Since 2-4 are very insoluble in common organic solvents, their UV-Vis spectra were recorded in phenol-methanol mixture $(1: 1 \mathrm{v} / \mathrm{v})$ (Figure 3$)$. The spectra of metal complexes are significantly different from that of the metal-free $\mathbf{1}$. Broadened absorption bonds of different intensity appear at $350-550 \mathrm{~nm}$ and can be attributed to electron transfers transitions with participation of $p$-orbitals of ligand and $d$-electronic shells of metal. It's worthy to note that there is a strong

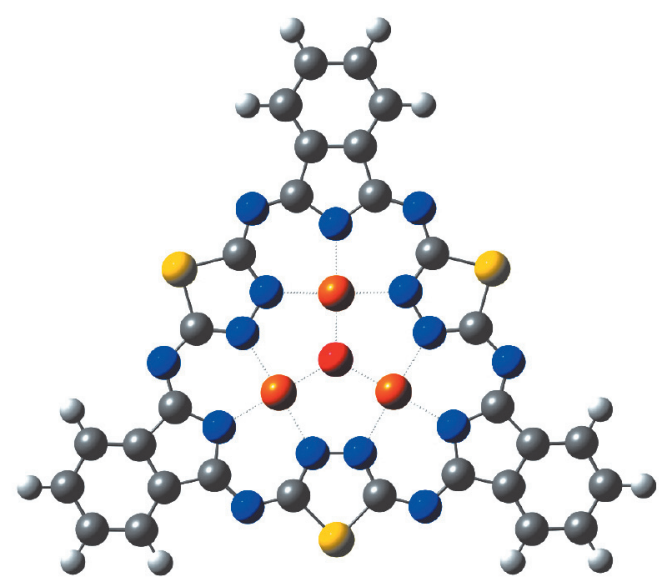

Figure 2. View of $[\mathrm{Hhp}+3 \mathrm{Cu}+\mathrm{O}]^{+}$complex optimized at DFT level. Selected distances $(\AA): \mathrm{Cu}-\mathrm{N}_{\text {iso }} 1.973-1.979$; $\mathrm{Cu}-\mathrm{N}_{\mathrm{td}}$ 1.981-1.997; $\mathrm{Cu}-\mathrm{O} 1.881 \div 1.891$ and $\mathrm{Cu}-\mathrm{Cu} 3.255-3.277$.

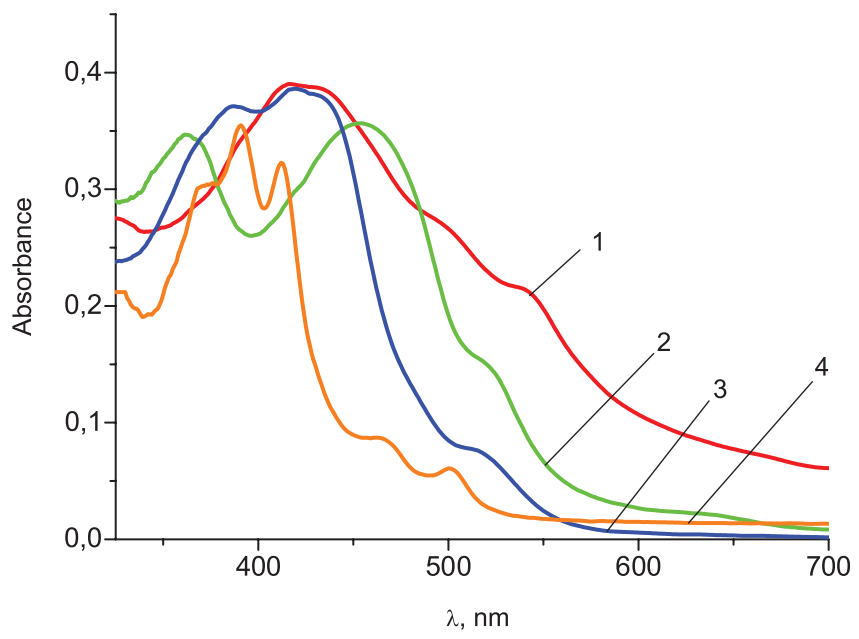

Figure 3. UV-Vis spectra of $\mathbf{1}$ in $\left(\mathrm{C}_{2} \mathrm{H}_{2} \mathrm{Cl}_{4}\right)$ and 2-4

in phenol-methanol $(1: 1 \mathrm{v} / \mathrm{v}) .1-$ Mn complex $c=0.369 \cdot 10^{-4} \mathrm{M}$; $2-\mathrm{Ni}$ complex $c=0.690 \cdot 10^{-4} \mathrm{M} ; \mathbf{3}-\mathrm{Cu}$ complex $c=0.678 \cdot 10^{-4} \mathrm{M}$; 4 - unsubstituted Mc $c=0.97 \cdot 10^{-5} \mathrm{M}$. influence of metal upon electronic structure as reflected in UV-vis spectra of these complexes. The bathochromic shifts of absorption are increased in row $\mathrm{Cu}, \mathrm{Mn}, \mathrm{Ni}$, what is just opposite to those observed in corresponding complexes of phthlocyanine. ${ }^{[29-32]}$

A signal at $3220 \mathrm{~cm}^{-1}$ corresponding to vibrations of inner N-H bonds in IR spectrum of metal-free compound 1 disappears upon complexation (Figure 4). The vibrations of $-\mathrm{C}=\mathrm{N}$-bonds, which appear as strong bands at $1624 \mathrm{~cm}^{-1}$ in spectrum of $\mathbf{1}$, are shifted in lower field to $1510 \mathrm{~cm}^{-1}$ during complexation.

\section{$T G$ and DSC Analysis}

Thermal behavior of the obtained complexes were studied via investigation of the manganese complex 4 in argon-oxygen atmosphere. The TG analysis of $\mathbf{4}$ shows a two-step degradation process (Figure 5). After initial loss of the moisture at $70-100{ }^{\circ} \mathrm{C}$, the pyrolysis of the complex with a loss of weight of $49.5 \%$ takes place in the range of $386-501{ }^{\circ} \mathrm{C}$. An intense elimination of $\mathrm{H}_{2} \mathrm{O}, \mathrm{CO}, \mathrm{CO}_{2}, \mathrm{NO}$, $\mathrm{NO}_{2}, \mathrm{SO}_{2}$ synchronously detected by mass-spectrometer shows that a profound oxidation of macrocyclic core takes place in this temperature range. Early it was communicated ${ }^{[23]}$ that metal-free 1 is decomposed at 460 to $510{ }^{\circ} \mathrm{C}$. Hence introduction of three atoms of manganese into coordination cavity of $\mathbf{1}$ led to decrease in its thermostability.

\section{Conclusion}

Homotrinuclear complexes of [30]trithiadodecaazahexaphyrine (2-4) were synthesized by interaction of $\mathbf{H}_{3}$ Hhp with nickel(II), copper(II) or manganese(II) acetates in phenol. All compounds were characterized by UV-Vis, IR spectroscopy, mass-spectrometry and elemental analysis. A complex of the formula $[\mathrm{Hhp}+3 \mathrm{Cu}+\mathrm{O}]^{+}$was detected in the mass-spectrum and elucidated by quantum chemistry calculations at DFT level. TG and DSC analysis of manganese complex 4 showed its high thermal stability.

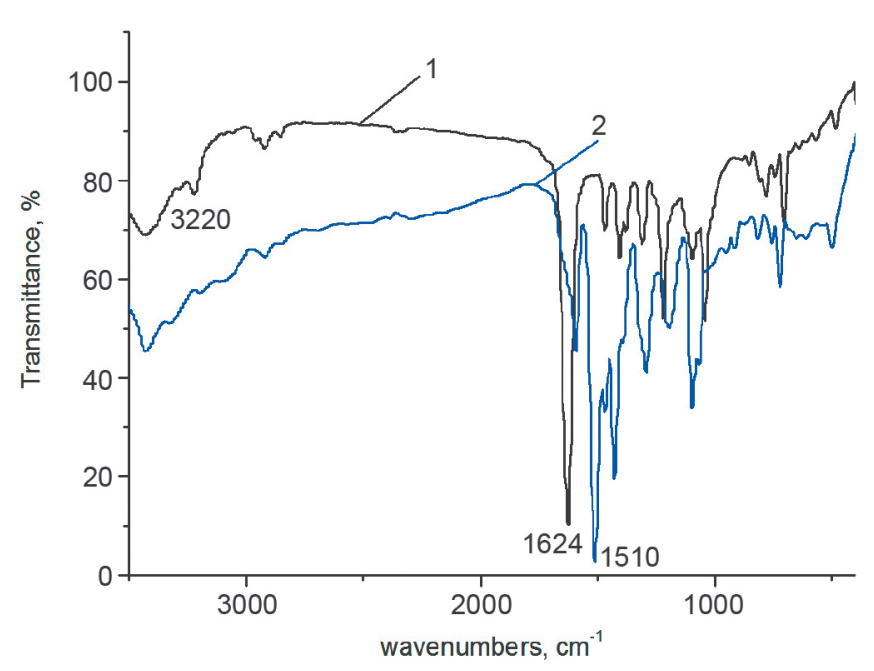

Figure 4. IR spectrum (KBr) of 1 (1) and its complex with $\mathrm{Cu} 2$ (2). 


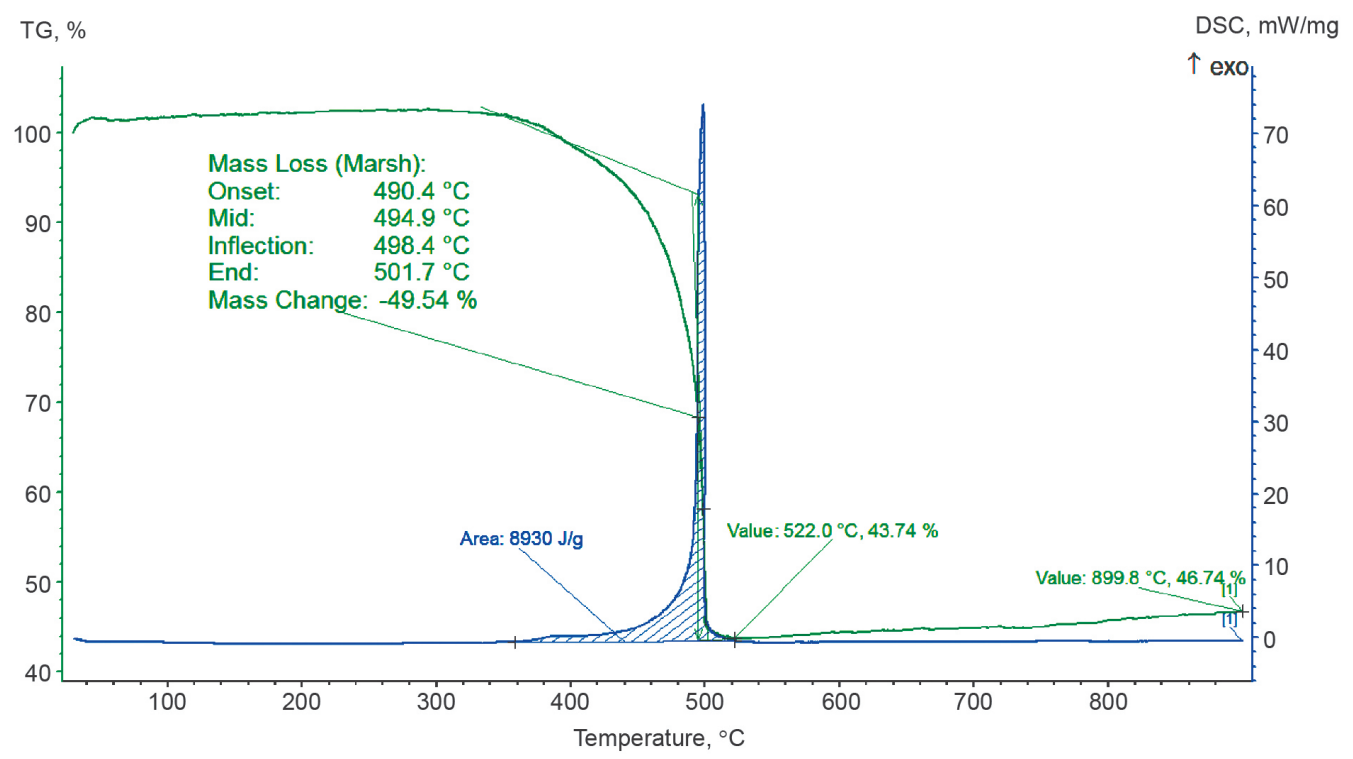

Figure 5. TG and DSC curves for 4 with heating rate of $5^{\circ} \mathrm{C} \cdot \mathrm{min}^{-1}$ in argon-oxygen atmosphere.

Acknowledgements. This work was financially supported by Russian Science Foundation (project № 14-23-00204).

\section{References}

1. Sessler J.L., Seidel D. Angew. Chem. Int. Ed. 2003, 42, 51345175.

2. Fukuzumi S., Ohkubo K., Ishida M., Preihs C., Chen B., Borden W.T., Kim D., Sessler J.L. J. Am. Chem. Soc. 2015, 137, 9780-9783.

3. Naoda K., Osuka A. J. Porphyrins Phthalocyanines 2014, 18, 652-658.

4. Eckert A.K., Trukhina O.N., Rodriguez-Morgade M.S., Danilova E.A., Islyaikin M.K., Torres T. Mendeleev Commun. 2010, 20, 192-194.

5. Rodriguez-Morgade M.S., Cabezon B., Esperanza S., Torres T. Chem. Eur. J. 2001, 7, 2407-2413.

6. Islyaikin M.K., Khelevina O.G., Danilova E.A., Lomova T.N. Izv. Vyssh. Uchebn. Zaved., Khim. Khim. Tekhnol. 2004, 47(5), 35 .

7. Ishida M., Shin J., Lim J.M., Lee B.S., Yoon M., Koide T., Sessler J.L., Osuka A., Kim D. J. Am. Chem. Soc. 2011, 133, 15533-15544.

8. Higashino T., Lim J.M., Miura T., Saito S., Shin J., Kim D., Osuka A. Angew. Chem. Int. Ed. 2010, 49, 4950-4954.

9. Lim J.M., Shin J., Tanaka Y., Saito S., Osuka A., Kim D. J. Am. Chem. Soc. 2010, 132, 3105-3114.

10. Islyaikin M.K., Danilova E.A., Yagodarova L.D., RodríguezMorgade M.S., Torres T. Org. Lett. 2001, 14, 2153-2156.

11. Kobayashi N., Inagaki S., Nemykin V.N., Nonomura T. Angew. Chem., Int. Ed. 2001, 40, 2710-2712.

12. Danilova E.A., Melenchuk T.V., Trukhina O.N., Zakharov A.V., Islyaikin M.K. Macroheterocycles 2010, 3, 33-37.

13. Bumbina N.V., Danilova E.A., Sharunov V.S., Filimonov S.I., Abramov I.G., Islyaikin M.K Mendeleev Commun. 2008, 18, 289-290.

14. Filatov M.S., Trukhina O.N., Islyaikin M.K. Macroheterocycles 2014, 7, 281-286.
15. Danilova E.A., Bumbina N.V., Islyaikin M.K. Macroheterocycles 2011, 4, 47-49.

16. Danilova E.A., Islyaikin M.K., Shtrygol S.Yu. Russ. Chem. Bull. 2015, 7, 1610-1615.

17. Filatov M.S., Trukhina O.N., Rodríguez-Morgade M.S., Islyaikin M.K., Koifman O.I., Torres T. J. Porphyrins Phthalocyanines 2014, 18, 1014-1020.

18. Danilova E.A., Islyaikin M.K. Macroheterocycles 2012, 5, 157-161.

19. Zakharov A.V., Shlykov S.A., Bumbina N.V., Danilova E.A., Krasnov A.V., Islyaikin M.K., Girichev G.V. Chem. Commun. 2008, 3573-3575.

20. Zakharov A.V., Shlykov S.A., Danilova E.A., Krasnov A.V., Islyaikin M.K., Girichev G.V. Phys. Chem. Chem. Phys. 2009, $11,8570-8579$.

21. Trukhina O.N., Rodrıguez-Morgade M.S., Wolfrum S., Caballero E., Snejko N., Danilova E.A., Gutierrez-Puebla E., Islyaikin M.K., Guldi D.M., Torres T. J. Am. Chem. Soc. 2010, 132, 12991-12999.

22. Lomova T.N., Mozhukhina E.G., Danilova E.A., Islyaikin M.K. Russ. J. Coord. Chem. 2006, 32, 837.

23. Trukhina O.N., Zhabanov Y.A., Krasnov A.V., Danilova E.A., Islyaikin M.K. J. Porphyrins Phthalocyanines 2011, 15, 12871291.

24. Hay P.J., Wadt W.R. J. Chem. Phys. 1985, 82, 270-284.

25. Granovsky A.A., Firefly version 8, http://classic.chem.msu.su/ gran/firefly/index.html.

26. Schmidt M.W., Baldridge K.K., Boatz J.A., Elbert S.T., Gordon M.S., Jensen J.H., Koseki S., Matsunaga N., Nguyen K.A., Su S., Windus T.L., Dupuis M., Montgomery J.A. J. Comput. Chem. 1993, 14, 1347-1363.

27. Andrienko G.A., www.chemcraftprog.com

28. Fernandez-Lazaro F., Torres T., Hauschel B., Hanack M. Chem. Rev. 1998, 98, 563-575.

29. Lever A.B.P. Adv. Inorg. Chem. Radiochem. 1965, 7, 27-114.

30. Whalley W. J. Chem. Soc. 1961, 866-869.

31. Anderson I.S., Bradbrook E.F., Cook A., Linstead R.P. J. Chem. Soc. 1938, 1151-1156.

32. Lever A.B.P., Wilshire J.P., Quan S.K. J. Am. Chem. Soc. 1979, $101,3368-3669$. 